\title{
Isolation, purification and characterization of PHB producing strains from dairy industry effluent
}

\author{
R. Rameshwari and M. Meenakshisundaram
}

\begin{abstract}
Polyhydroxybutyrates are biodegradable thermopolyesters which are synthesised by many bacteria under stress conditions they are reported to produce biopolymers like PHB, which can be produced intracellularly as carbon and energy reserves. In this present study, twelve bacterial isolates isolated from dairy industry effluent collected from Aawin Industry, Trichy. However, only one bacterial isolate (DE 6) is selected based on high PHB production $0.068 \mathrm{mg} / \mathrm{ml}$. All the 12 bacterial isolates were characterised by morphological and biochemical test. Optimisation of culture conditions such as $\mathrm{pH}$, temperature and incubation time was carried out for the isolate (DE 6). The maximum PHB yield was recorded under dry weight basis in minimal agar media as glucose as the sole carbon source at $\mathrm{pH} 6$ and temperature $40^{\circ} \mathrm{C}$ for 72 hours.
\end{abstract}

KEY WORDS : Polyhydroxybutyrate, Bioplastic, Biosynthesis

HOW TO CITE THIS PAPER : Rameshwari, R. and Meenakshisundaram, M. (2018). Isolation, purification and characterization of PHB producing strains from dairy industry effluent. Res. J. Animal Hus. \& Dairy Sci., 9(1) : 14-19 : DOI: 10.15740/HAS/RJAHDS/9.1/14-19. Copyright@ 2018: Hind Agri-Horticultural Society. 